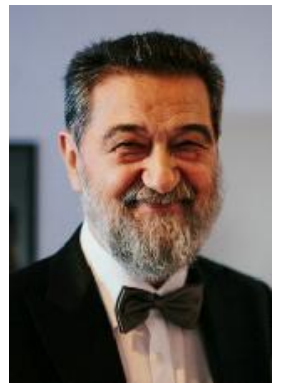

\title{
CURRENT BIOMEDICAL SCIENTIFIC IMPACT (2013) OF INSTITUTIONS, ACADEMIC JOURNALS AND RESEARCHERS IN THE REPUBLIC OF MACEDONIA
}

\section{Mirko Spiroski}

Faculty of Medicine, Ss Cyril and Methodius University, Skopje, Republic of Macedonia; Founder and Editor-in-Chief of the Macedonian Journal of Medical Sciences

Corresponding Author: Prof. Dr. Mirko Spiroski, Faculty of Medicine, Ss Cyril and Methodius University, Skopje, 1109 Skopje, Republic of Macedonia; E-mail: mspiroski@yahoo.com

Running Head: Spiroski: Macedonian Biomedical Science, 2013

\begin{abstract}
Aim: To analyse current ranking (2013) of institutions, journals and researchers in the Republic of Macedonia.

Material and Methods: the country rankings of R. Macedonia were analyzed with SCImago Country \& Journal Rank (SJR) for subject area Medicine in the years 1996-2013, and ordered by H-index. SCImago Institutions Rankings for 2013 was used for the scientific impact of biomedical institutions in the Republic of Macedonia. Journal metrics from Elsevier for the Macedonian scholarly journals for the period 2009 \pm 2013 were performed. Source Normalized Impact per Paper (SNIP), the Impact per Publication (IPP), and SCImago Journal Rank (SJR) were analysed. Macedonian scholarly biomedical journals included in Google Scholar metrics $(2013,2012)$ were analysed with h5-index and h5-median (June 2014). A semantic analysis of the PubMed database was performed with GoPubMed on November 2, 2014 in order to identify published papers from the field of biomedical sciences affiliated with the country of Macedonia. + DIQITV3 XECOKIRU3HUKIVRIW DHZ DVXXHEIIRU author impact analysis and the calculation of the Hirsh-index based on Google Scholar query.

Results: The rank of subject area Medicine of R. Macedonia according to the SCImago Journal \& Country Rank (SJR) is 110th in the world and 17th in Eastern Europe. Of 20 universities in Macedonia, only Ss Cyril and Methodius University, Skopje, and the University St Clement of Ohrid, Bitola, are listed in the SCImago Institutions Rankings (SIR) for 2013. A very small number of Macedonian scholarly journals is included in Web of Sciences (2), PubMed (1), PubMed Central (1), SCOPUS (6), SCImago (6), and Google Scholar metrics (6). The rank of Hirsh index (h-index) was different from the rank of number of abstracts indexed in PubMed for the top 20 authors from R. Macedonia.

Conclusion: The current biomedical scientific impact (2013) of institutions, academic journals and researchers in R. Macedonia is very low. There is an urgent need for organized measures to improve the quality and output of institutions, scholarly journals, and researchers in R. Macedonia in order to achieve higher international standards.
\end{abstract}

Key words: medical science; Scopus database; citation metrics; h-index; Republic of Macedonia.

\section{Introduction}

Scientific impact can be measured by citation analysis of the ranks of institutions (coun-

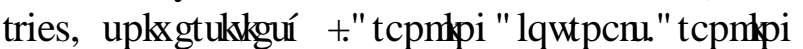
researchers, and ranking articles (Altmetric). Am- plification of citations (Scientific networks) can influence the citation-based metrics. In this paper ranking of institutions, journals and researchers are presented, but amplification of citations and altmetrics are not analysed or presented (Fig. 1). 


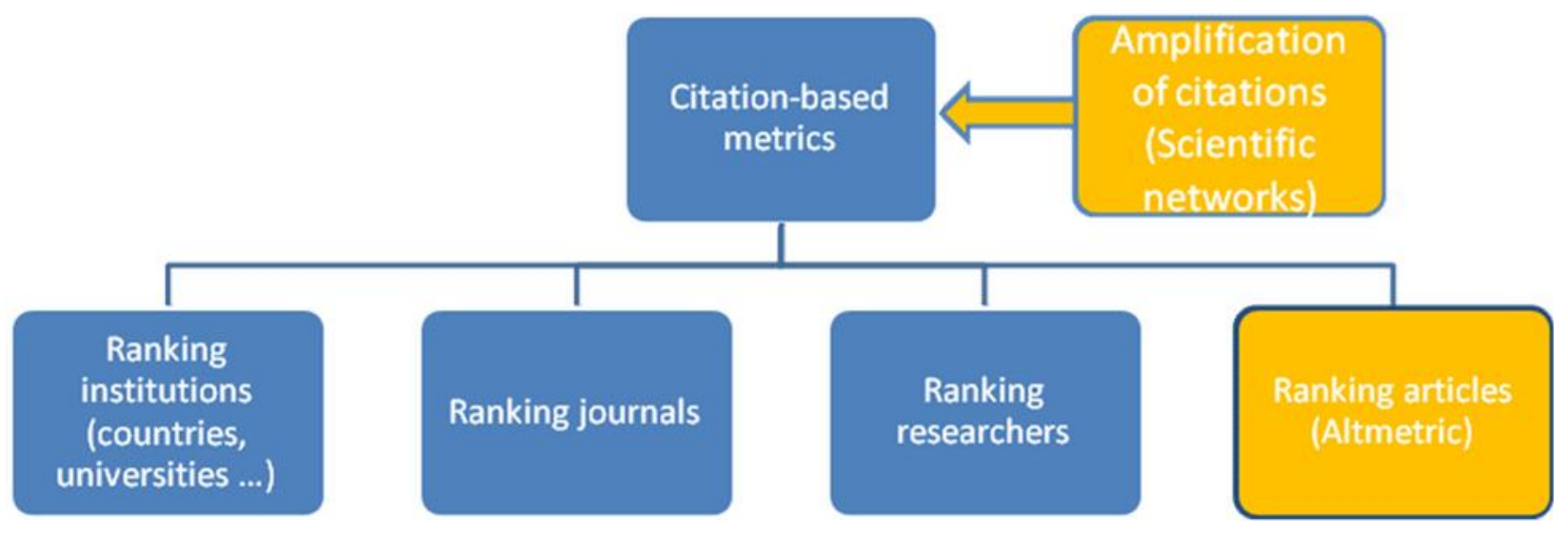

Figure 1 - Using citation analysis to measure research impact

There are several rankings of the universities in the world which use different data for analysis (Table 1). Every year, SCImago Research Group publishes two reports on instituteons, the Ibero-American SIR (SCImago Research Group) and the Global SIR (SCImago Research Group). The former usually appears in March and includes all higher education institutions of Ibero-American countries with at least one document published in the Scopus data base during the five-year period. The Global SIR is published in July and it takes into account organizations from any country with at least 100 documents published in the last year of the fiveyear period. The chronological range extends from 2003 to 2012 and each report represents the five-year period with indicators [1].

At the moment there are five public universities and fifteen private universities, or in total twenty accredited universities, in R. Macedonia (Table 2). The oldest Public University in the Republic of Macedonia is Ss Cyril and Methodius University, Skopje, established in 1949.

The impact factor (IF) of an academic journal is a measure reflecting the average number of citations of recent articles published in the journal [2]. The impact factor was devised by Eugene Garfield, the founder of the Institute for Scientific Information. Impact factors are calculated yearly starting from 1975 for those journals that are indexed in the Journal Citation Reports [3]. Because "the impact factor is not
Table 1

Global rankings of World Universities

- Academic Ranking of World Universities

- Times Higher Education World University Rankings

- Times Higher Education World Reputation Rankings

- G-factor

- Global University Ranking

- HEEACT-Ranking of Scientific Papers

- High Impact Universities: Research Performance Index

- Human Resources \& Labor Review

- Leiden Ranking

- Newsweek

- Professional Ranking of World Universities

- QS World University Rankings

- QS Asian University Rankings

- QS Latin American University Rankings

- SCImago Institutions Rankings

- U-Multirank

- University Ranking by Academic Performance

- Webometrics

- Wuhan University

always a reliable instrument", in 2007 the European Association of Science Editors (EASE) issued an official statement recommending "that journal impact factors are used only-and cautiously-for measuring and comparing the influence of entire journals, but not for the assessment of single papers, and certainly not for the assessment of researchers or research programmes" [4]. The International Council for Science (ICSU) Committee on Freedom and Responsibility in the Conduct of Science (CFRS) issued a "statement on publication practices and indices and the role of peer review in research assessment", suggesting many possible soluteons - e.g. considering a limited number of pub- 
lications per year to be taken into consideration for each scientist, or even penalising scientists for an excessive number of publications per year - e.g. more than 20 [5]. In 2010, the Deutsche Forschungsgemeinschaft (German Research Foundation) published new guidelines to evaluate articles only and no bibliometric information on candidates to be evaluated in all decisions concerning "performance-based funding allocations, postdoctoral qualifications, appointments, or reviewing funding proposals, in which increasing importance has been given to numerical indicators such as the $\mathrm{h}$-index and the impact factor" [6]. This decision follows simi- lar ones by the National Science Foundation (US) [7] and the Research Assessment Exercise (UK) [8]. In response to growing concerns over the inappropriate use of journal impact factors in evaluating scientific outputs and scientists themselves, the American Society for Cell Biology together with a group of editors and publishers of scholarly journals created the San Francisco Declaration on Research Assessment (DORA). Released in May of 2013, DORA has garnered support from thousands of individuals and hundreds of institutions which have endorsed the document on the DORA website [9].

Table 2

Current list of universities in the Republic of Macedonia (2013)

\section{Public Universities}

1. Ss. Cyril and Methodius University, Skopje (UC\&M)

2. St. Clement of Ohrid University, Bitola (UCO)

3. Goce Delčev University, Štip (GDU)

4. St. Paul The Apostle University for Information Science and Technology, Ohrid (UIST)

5. State University of Tetovo (SUT)

Private Universities and Faculties

1. International Balkan University

2. Euro College Kumanovo

3. South East European University, Tetovo

4. International University of Struga

5. FON University, Skopje

6. University American College, Skopje

7. University of Tourism and Management, Skopje

8. Slavic University, Skopje

9. European University-Republic of Macedonia, Skopje

10. EuroCollege University of Studies, "Struga"

11. MIT Faculties, Skopje

12. New York University, Skopje

13. University for Audiovisual Arts - Parisian European Film Academy ESRA - Skopje

14. International Summer University (Skopje)

15. BAS - Business Academy Smilevski - Skopje

There are several metrics of individual impact. Many of these are ranking measures providing quantitative estimates of the relative importance of a scientist [10]. The recently introduced h-index [11], which combines the impact of the papers of a scientist with his/her productivity, is by far the most popular. Hindex is a cumulative measure and thus combines all the works of a scientist during his/her whole research career. However, research productivity and impact vary with time, with dif- ferent scientists having distinct career trajectories. Hence, the Author Impact Factor (AIF) was introduced, which is the extension of the IF to authors [12]. AIF is capable of capturing trends and variations of the impact of the scientific output of scholars in time, unlike the hindex, which is a growing measure taking into account the whole career path.

There are several published papers dealing with biomedical scientific impact in $\mathrm{R}$. Macedonia. We present the state of the current 
scientific influence of Macedonian medical journals, their inclusion in medical databases and consequently the influence of Macedonian medical scientists in the world. Macedonian biomedical scientists included in the BiomedExperts Database contribute $0.006 \%$ to this database [13]. We found a very limited scientific influence of Macedonian medical journals according to the internationally recognized citation metrics indexes because only one journal (Prilozi) was currently indexed in PubMed and Google Scholar [14]. The SCImago database was also used for analysis of country rank, journal rank and $\mathrm{H}$-index in the field of medicine in R. Macedonia. These parameters/indexes are in the range of the other former Yugoslav countries, but again only Prilozi and the Macedonian Journal of Medical Sciences are included in this database [15]. Mukaetova-Ladinska E and Korneti-Pekevska K [16] emphasized the fact that undergraduate and postgraduate course organizers have to engage the students as early as possible in their academic career. On the other hand, the academic staff should organize good research in our institutions, and should strive to publish a higher level of peer-reviewed papers [16].

The aim of this study was to analyse current ranking (2013) of institutions, journals and researchers in R. Macedonia.

\section{Material and Methods}

\section{Ranking institutions in the Republic of Macedonia}

Country rankings of R. Macedonia was analyzed with SCImago Country \& Journal Rank (SJR) for subject area Medicine, with all categories of the selected area, with all regions of Eastern Europe, in the years 1996-2013, and ordered by H-index (accessed on October, 2014) $[17,18]$. In this report we used SCImago Institutions Rankings for 2013 year [1].

\section{Ranking journals in the Republic of Macedonia}

Journal metrics from Elsevier for the Macedonian scholarly journals for the period of 2009-2013 (Scopus data source, July 2014) was performed [19]. Source Normalized Impact per Paper (SNIP) [20], the Impact per Publica- tion (IPP) [21], and SCImago Journal Rank (SJR) [18] were analysed. Macedonian scholarly biomedical journals included in Google Scholar metrics $(2013,2012)$ were analysed with h5-index and h5-median [22]. The h5-index of a publication is the largest $h$ number such that at least $\mathrm{h}$ articles in that publication were cited at least h times each. For example, a publication with five articles cited by, respectively, 17, 9, 6, 3 , and 2 , has the h5-index of 3 . The h5-median of a publication is the median of the citation counts in its h-core. Scholar Metrics are currently based on our index as it was in June 2014.

\section{Ranking researchers in the Republic of Macedonia}

A semantic analysis of PubMed database was performed with GoPubMed on November 02,2014 in order to identify published papers from the field of biomedical sciences affiliated with the country Macedonia. Additional analysis was performed using PubMed with the terms: "macedonia (republic)" [MeSH Terms] OR "macedonia" [All Fields] AND "republic" [All Fields] OR "macedonia (republic)" [All Fields] OR "macedonia" [All Fields] NOT Greece [Af filiation] [23].

Harzing's Publish or Perish software [24] was used for author impact analysis and calculation of the Hirsh-index based on Google Scholar query.

\section{Results}

\section{Ranking institutions in the Republic of Macedonia}

Country rank of subject area Medicine in the World (a) and the Eastern Europe region (b) of R. Macedonia for the period 1996-2013 year ordered by Hirsh index (H-index) is shown in Fig. 2. The first three places in the world belongs to United States $(\mathrm{H}$-index $=1053)$, United Kingdom $(\mathrm{H}$-index $=692)$, and Canada $(\mathrm{H}-$ index $=584)$. $\mathrm{R}$. Macedonia is in the $110^{\text {th }}$ place with an $\mathrm{H}$-index of 45 . From 24 countries grouped in Eastern Europe, R. Macedonia is in the $17^{\text {th }}$ place. Bosnia and Herzegovina and Montenegro have a lower rank than R. Macedonia, but Slovenia, Croatia and Serbia have a higher rank with $\mathrm{H}$-indexes of 108, 102 and 64 respectively (Fig. 2). 
a)

\begin{tabular}{|l|c|c|c|c|c|c|}
\hline \multicolumn{1}{|c|}{ Country } & Documents & $\begin{array}{c}\text { Citable } \\
\text { documents }\end{array}$ & Citations & Self-Citations & $\begin{array}{c}\text { Citations per } \\
\text { Document }\end{array}$ & H index \\
\hline 1 國 United States & 2.554 .598 & 2.276 .467 & 57.895 .780 & 22.237 .666 & 25,21 & 1.053 \\
\hline 2 Erata United Kingdom & 733.871 & 618.015 & 14.802 .891 & 2.700 .202 & 22,11 & 692 \\
\hline 3 [4 Canada & 333.460 & 300.642 & 7.421 .683 & 975.981 & 26,20 & 584 \\
\hline
\end{tabular}

\begin{tabular}{|c|c|c|c|c|c|c|}
\hline 81 IO Sri Lanka & 2.849 & 2.569 & 28.810 & 2.309 & 14,43 & 67 \\
\hline 82 Ⓛatvia & 1.306 & 1.265 & 23.919 & 862 & 23,96 & 67 \\
\hline 83 [. Cameroon & 2.938 & 2.782 & 31.958 & 3.376 & 15,09 & 64 \\
\hline 84 Serbia & 8.685 & 8.134 & 35.716 & 3.896 & 16,92 & 64 \\
\hline $85 \square$ Zambia & 1.695 & 1.558 & 26.067 & 2.734 & 20,72 & 64 \\
\hline 86 E Jordan & 4.602 & 4.418 & 32.873 & 2.183 & 8,74 & 62 \\
\hline 87 E Nepal & 3.956 & 3.506 & 28.279 & 3.047 & 10,18 & 62 \\
\hline 88 루 Panama & 886 & 829 & 18.021 & 743 & 31,47 & 62 \\
\hline 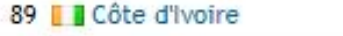 & 1.930 & 1.815 & 21.182 & 2.123 & 12,68 & 61 \\
\hline $90 \unrhd$ Ecuador & 1.748 & 1.635 & 21.251 & 1.682 & 15,17 & 61 \\
\hline 91 Ethiopia & 3.204 & 3.081 & 29.766 & 3.862 & 13,75 & 60 \\
\hline $92-$ Burkina Faso & 1.858 & 1.771 & 22.091 & 2.391 & 14,49 & 58 \\
\hline 93 - Cyprus & 2.021 & 1.839 & 19.970 & 1.349 & 14,80 & 58 \\
\hline $94 \Xi$ Gabon & 1.001 & 933 & 15.165 & 915 & 17,90 & 57 \\
\hline 95 Jamaica & 1.964 & 1.813 & 21.141 & 2.103 & 12,75 & 57 \\
\hline 96 [] Guatemala & 1.072 & 1.000 & 14.229 & 662 & 16,66 & 55 \\
\hline 97 Mozambique & 921 & 870 & 15.945 & 1.184 & 21,62 & 55 \\
\hline 98 Algeria & 1.911 & 1.806 & 18.325 & 818 & 13,88 & 53 \\
\hline $99 \square$ Bolivia & 892 & 861 & 13.010 & 766 & 16,81 & 52 \\
\hline 100 Malta & 1.120 & 1.019 & 14.674 & 516 & 19,75 & 52 \\
\hline 101 Cambodia & 1.043 & 961 & 15.116 & 1.335 & 20,68 & 51 \\
\hline 102 Papua New Guinea & 859 & 818 & 12.647 & 1.263 & 16,32 & 51 \\
\hline 103 E Sudan & 1.834 & 1.737 & 16.782 & 1.708 & 12,76 & 50 \\
\hline $104 \supseteq$ Botswana & 722 & 659 & 12.688 & 496 & 24,99 & 49 \\
\hline 105 Mali & 1.051 & 1.013 & 13.045 & 847 & 16,39 & 49 \\
\hline $106 \mathbb{N}$ Trinidad and Tobago & 1.408 & 1.267 & 14.224 & 833 & 11,59 & 49 \\
\hline $107 \square$ Oman & 2.751 & 2.419 & 16.285 & 1.330 & 7,79 & 47 \\
\hline 108 tit Georgia & 953 & 881 & 9.604 & 316 & 11,77 & 45 \\
\hline $109=$ Monaco & 541 & 471 & 7.379 & 214 & 16,24 & 45 \\
\hline 110 aㅡㄹ Macedonia & 1.514 & 1.410 & 10.753 & 518 & 9,13 & 45 \\
\hline $111[$ Benin & 1.001 & 952 & 9.573 & 1.199 & 14,18 & 44 \\
\hline $112 \sqrt{ }$ Congo & 1.370 & 1.264 & 11.693 & 877 & 10,28 & 44 \\
\hline 113 Qatar & 2.552 & 2.339 & 14.374 & 1.370 & 6,73 & 44 \\
\hline
\end{tabular}


b)

\begin{tabular}{|c|c|c|c|c|c|c|}
\hline Country & Documents & $\begin{array}{l}\text { Citable } \\
\text { documents }\end{array}$ & Citations & Self-Citations & $\begin{array}{l}\text { Citations per } \\
\text { Document }\end{array}$ & $\mathrm{H}$ index \\
\hline $1 \equiv$ Poland & 95.956 & 91.611 & 801.211 & 97.527 & 9,67 & 240 \\
\hline 2 L $=$ Czech Republic & 46.929 & 44.735 & 412.465 & 44.294 & 9,67 & 192 \\
\hline 3 D Hungary & 29.619 & 27.881 & 411.305 & 32.523 & 15,26 & 186 \\
\hline $4=$ Russian Federation & 39.090 & 38.251 & 360.573 & 26.818 & 10,38 & 173 \\
\hline 5 Ea Slovakia & 12.476 & 11.800 & 109.070 & 8.213 & 9,60 & 113 \\
\hline 6 Slovenia & 10.901 & 10.316 & 120.814 & 11.343 & 13,36 & 108 \\
\hline $7 \geq$ Croatia & 19.714 & 18.599 & 118.671 & 17.521 & 6,88 & 102 \\
\hline 8 [IRomania & 12.127 & 11.483 & 86.742 & 5.474 & 9,88 & 98 \\
\hline $9 \pm$ Bulgaria & 10.052 & 9.652 & 79.047 & 4.195 & 8,00 & 96 \\
\hline $10 \boxminus$ Estonia & 3.832 & 3.695 & 67.161 & 4.284 & 20,33 & 95 \\
\hline $11 \boxminus$ Ukraine & 5.079 & 4.989 & 55.503 & 2.751 & 12,00 & 87 \\
\hline $12 \boxminus$ Lithuania & 3.595 & 3.465 & 48.156 & 2.057 & 19,17 & 84 \\
\hline $13 \square$ Belarus & 1.941 & 1.906 & 22.396 & 1.402 & 12,18 & 67 \\
\hline $14 \equiv$ Latvia & 1.306 & 1.265 & 23.919 & 862 & 23,96 & 67 \\
\hline 15 rad Serbia & 8.685 & 8.134 & 35.716 & 3.896 & 16,92 & 64 \\
\hline $16+$ Georgia & 953 & 881 & 9.604 & 316 & 11,77 & 45 \\
\hline 17 aㅐㅂ Macedonia & 1.514 & 1.410 & 10.753 & 518 & 9,13 & 45 \\
\hline $18 \llbracket$ Bosnia and Herzegovina & 1.919 & 1.828 & 7.511 & 780 & 7,61 & 36 \\
\hline $19 \Xi$ Armenia & 781 & 744 & 5.288 & 248 & 9,19 & 34 \\
\hline $20 \square$ Albania & 478 & 448 & 3.581 & 147 & 10,54 & 29 \\
\hline $21[0]$ Moldova & 274 & 262 & 2.028 & 53 & 10,10 & 25 \\
\hline $22 \square$ Azerbaijan & 1.550 & 1.528 & 2.931 & 60 & 5,23 & 24 \\
\hline $23 \mathbf{G}$ Montenegro & 226 & 220 & 592 & 12 & 3,90 & 12 \\
\hline 24 :클 Bouvet Island & 1 & 1 & 5 & 0 & 5,00 & 1 \\
\hline
\end{tabular}

Figure 2 - Country rank of subject area Medicine in the World (a) and in the Eastern Europe region (b) of the Republic of Macedonia for the period 1996-2013 ordered

by Hirsh index (H-index) [2].

The results of SCImago Institutions Rankings (SIR) for R. Macedonia are shown in Fig. 3. From 2009-12 only Ss Cyril and Methodius University in Skopje (UC\&M) was included in the SIR with a world rank of 1726 to 1821 . The regional rank of UC\&M in Eastern Europe was gradually increased from $156^{\text {th }}$ in 2009 to $127^{\text {th }}$ in 2013. In 2013 University St. Clement of Ohrid, Bitola (UCO) was included in SIR for the first time with the world rank of 2737 and regional rank of 333. The results have shown that only two educational institutions from R. Macedonia published at least 100 documents in the last year of the five-year period (Fig. 3).

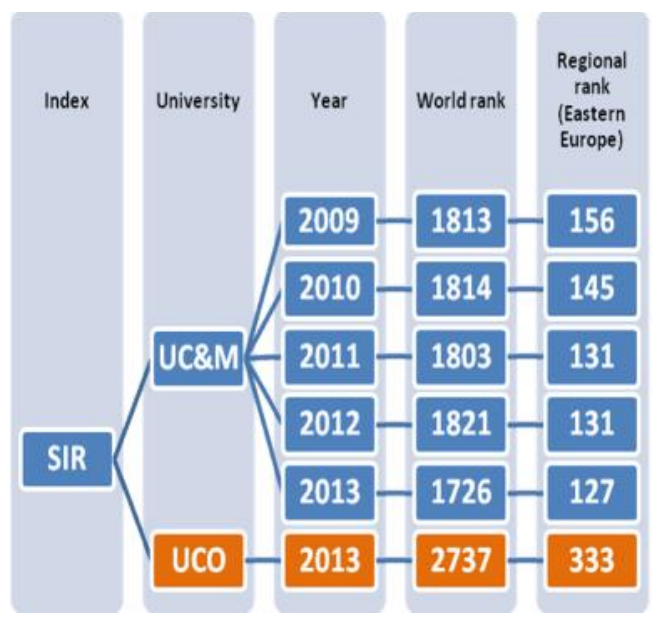

Figure 3 - The results of SCImago Institutions Rankings (SIR) for Republic of Macedonia [1] 
Ranking journals in the Republic of Macedonia

Of all Macedonian biomedical journals only the journal Prilozi is included and indexed in PubMed, only the Balkan Journal of Medical Genetics is included in PubMed Central, but only the Macedonian Journal of Chemistry and Chemical Engineering and Balkan Journal of Medical Genetics are included in Web of Science and have an Impact Factor [0.310 and 0.167 (2012-2013), respectively].

The Journal metrics from Elsevier (http://www.journalmetrics.com/) for Macedonian scholarly journals for the period 2009-13 (Scopus data source, July 2014) is shown in Table 3. Six medical journals from R. Macedonia are included in the Scopus database (Macedonian Journal of Chemistry and Chemical Engineering, Macedonian Journal of Medical Sciences, Balkan Journal of Medical Genetics, Prilozi, Journal of Special Education and Rehabilitation and BANTAO Journal). All the journals have print ISSN, but only three of them have electronic ISSN (Macedonian Journal of Chemistry and Chemical Engineering, Macedonian Journal of Medical Sciences, and Journal of Special Education and Rehabilitation). Source Normalized Impact per Paper (SNIP) was calculated for only three journals (Macedonian Journal of Chemistry and Chemical Engineering, Macedonian Journal of Medical Sciences, and Balkan Journal of Medical Genetics) and was gradually increased. Impact per Publication (IPP) was also calculated for the three mentioned journals with a gradual increase in the period of 2009-13. SCImago Journal Rank (SJR) was calculated for four journals (Macedonian Journal of Chemistry and Chemical Engineering, Macedonian Journal of Medical Sciences, Balkan Journal of Medical Genetics and Prilozi) with increased values in 2013 for Macedonian Journal of Medical Sciences and Balkan Journal of Medical Genetics, a decreased value for Macedonian Journal of Chemistry and Chemical Engineering, and without a value for Prilozi (Table 3).

Table 3

Journal metrics from Elsevier (http://www.journalmetrics.com/) for Macedonian scholarly journals for the period 2009-13 (Scopus data source, July 2014)

\begin{tabular}{|c|c|c|c|c|c|c|c|c|c|c|c|c|c|c|c|c|c|}
\hline \multirow{2}{*}{$\begin{array}{l}\text { Scholarly } \\
\text { Journal }\end{array}$} & \multicolumn{2}{|c|}{ ISSN } & \multicolumn{5}{|c|}{$\begin{array}{l}\text { Source Normalized Impact per Paper } \\
\text { (SNIP) }\end{array}$} & \multicolumn{5}{|c|}{ Impact per Publication (IPP) } & \multicolumn{5}{|c|}{ SCImago Journal Rank (SJR) } \\
\hline & pISSN & eISSN & \begin{tabular}{|l|}
2009 \\
SNIP \\
\end{tabular} & \begin{tabular}{l|l|}
2010 \\
SNIP \\
\end{tabular} & $\begin{array}{l}2011 \\
\text { SNIP }\end{array}$ & $\begin{array}{l}2012 \\
\text { SNIP }\end{array}$ & \begin{tabular}{|l|}
2013 \\
SNIP \\
\end{tabular} & $\begin{array}{c}2009 \\
\text { IPP }\end{array}$ & $\begin{array}{l}2010 \\
\text { IPP }\end{array}$ & \begin{tabular}{|c|}
2011 \\
IPP
\end{tabular} & $\begin{array}{l}2012 \\
\text { IPP }\end{array}$ & $\begin{array}{l}2013 \\
\text { IPP }\end{array}$ & $\begin{array}{c}2009 \\
\text { SJR }\end{array}$ & \begin{tabular}{c|c}
2010 \\
SJR
\end{tabular} & $\begin{array}{c}2011 \\
\text { SJR }\end{array}$ & $\begin{array}{c}2012 \\
\text { SJR }\end{array}$ & $\begin{array}{c}2013 \\
\text { SJR }\end{array}$ \\
\hline $\begin{array}{l}\text { Macedonian } \\
\text { Journal of } \\
\text { Chemistry } \\
\text { and Chemical } \\
\text { Engineering } \\
\end{array}$ & 03500136 & 18575625 & 0.024 & $0.344 \uparrow$ & $0.809 \uparrow$ & $0.600 \downarrow$ & $0.557 \uparrow$ & 0.059 & $0.361 \uparrow$ & $0.909 \uparrow$ & $0.931 \uparrow$ & $0.623 \uparrow$ & 0.108 & $0.188 \uparrow$ & $0.300 \uparrow$ & $0.286 \downarrow$ & $0.226 \downarrow$ \\
\hline $\begin{array}{l}\text { Macedonian } \\
\text { Journal of } \\
\text { Medical } \\
\text { Sciences } \\
\end{array}$ & 18575749 & 18575773 & 0.057 & $0.070 \uparrow$ & $0.167 \uparrow$ & $0.177 \uparrow$ & $0.256 \uparrow$ & 0.091 & $0.045 \downarrow$ & $0.163 \uparrow$ & $0.177 \uparrow$ & $0.269 \uparrow$ & 0.144 & $0.158 \uparrow$ & $0.136 \downarrow$ & $0.127 \downarrow$ & $0.213 \uparrow$ \\
\hline $\begin{array}{l}\text { Balkan } \\
\text { Journal of } \\
\text { Medical } \\
\text { Genetics* }\end{array}$ & 13110160 & - & 0.115 & $0.109 \downarrow$ & $0.153 \uparrow$ & $0.119 \uparrow$ & $0.185 \uparrow$ & 0.080 & $0.083 \uparrow$ & $0.246 \uparrow$ & $0.107 \uparrow$ & $0.155 \uparrow$ & 0.116 & $0.118 \uparrow$ & $0.150 \uparrow$ & $0.115 \downarrow$ & $0.117 \uparrow$ \\
\hline Prilozi & 03513254 & - & - & - & - & - & - & - & - & - & - & - & 0.148 & $0.123 \downarrow$ & $0.145 \downarrow$ & $0.160 \uparrow$ & - \\
\hline $\begin{array}{l}\text { Journal of } \\
\text { Special } \\
\text { Education } \\
\text { and } \\
\text { Rehabilitation }\end{array}$ & 14096099 & $1857663 X$ & - & - & 0.000 & 0.000 & 0.119 & - & - & 0.000 & 0.000 & 0.070 & - & - & 0.101 & 0.100 & 0.120 \\
\hline $\begin{array}{l}\text { BANTAO } \\
\text { Journal }\end{array}$ & 13122517 & - & - & - & - & - & 0.000 & - & - & - & - & 0.000 & - & - & - & - & 0.102 \\
\hline
\end{tabular}

$\uparrow \downarrow$ Increase or decrease in comparison with 2009; * currently published by Macedonian Academy of Sciences and Arts, Section of Biological and Medical Sciences. 
Table 4

Academic journals from Republic of Macedonia deposited and indexed in SCImago for 2013

\begin{tabular}{|c|c|c|c|c|c|c|c|c|c|c|}
\hline Title & Type & SJR & $\begin{array}{c}\mathrm{H} \\
\text { index }\end{array}$ & $\begin{array}{l}\text { Total } \\
\text { Docs. } \\
\text { (2013) }\end{array}$ & $\begin{array}{l}\text { Total } \\
\text { Docs. } \\
\text { (3years) }\end{array}$ & $\begin{array}{l}\text { Total } \\
\text { Refs. }\end{array}$ & $\begin{array}{c}\text { Total } \\
\text { Cites } \\
\text { (3years) }\end{array}$ & $\begin{array}{l}\text { Citable } \\
\text { Docs. } \\
\text { (3years) }\end{array}$ & $\begin{array}{l}\text { Cites / } \\
\text { Doc. } \\
\text { (2years) }\end{array}$ & $\begin{array}{l}\text { Ref. / } \\
\text { Doc. }\end{array}$ \\
\hline Filomat* & $\mathrm{J}$ & 0.354 & 9 & 163 & 232 & 3,019 & 170 & 231 & 0.76 & 18.52 \\
\hline $\begin{array}{l}\text { Macedonian } \\
\text { Journal of } \\
\text { Chemistry and } \\
\text { Chemical } \\
\text { Engineering** }\end{array}$ & $\mathrm{J}$ & 0.226 & 8 & 24 & 63 & 1,202 & 48 & 61 & 0.45 & 50.08 \\
\hline $\begin{array}{l}\text { Macedonian } \\
\text { Journal of } \\
\text { Medical Sciences }\end{array}$ & $\mathrm{J}$ & 0.213 & 5 & 72 & 174 & 1,977 & 59 & 172 & 0.30 & 27.46 \\
\hline $\begin{array}{l}\text { Journal of Special } \\
\text { Education and } \\
\text { Rehabilitation }\end{array}$ & $\mathrm{J}$ & 0.120 & 1 & 14 & 66 & 423 & 3 & 54 & 0.06 & 30.21 \\
\hline $\begin{array}{l}\text { Balkan Journal of } \\
\text { Medical Genetics }\end{array}$ & $\mathrm{J}$ & 0.117 & 5 & 0 & 73 & 0 & 11 & 72 & 0.16 & 0.00 \\
\hline BANTAO Journal & $\mathrm{J}$ & 0.102 & 0 & 0 & 11 & 0 & 0 & 10 & 0.00 & 0.00 \\
\hline Prilozi*** & $\mathrm{J}$ & 0 & 0 & 0 & 0 & 0 & 0 & 0 & 0.00 & 0.00 \\
\hline
\end{tabular}

* published by University of Nish, Serbia and erroneously classified as in Macedonia; $j$, journal;

** published by The Society of Chemists and Technologists of Macedonia and erroneously classified as in Serbia; *** published by Macedonian Academy of Sciences and Arts, Section of Biological and Medical Sciences, and omitted from Scopus indexation and SCImago analysis in 2013.

The results of academic journals from $\mathrm{R}$. Macedonia deposited and indexed in SCImago for 2013 year are shown in Table 4. The journal Filomat is published by the University of Nish, Serbia, and erroneously classified as in Macedonia. The Macedonian Journal of Chemistry and Chemical Engineering is published by The Society of Chemists and Technologists of Macedonia and erroneously classified as in Serbia. Prilozi is published by the Macedonian Academy of Sciences and Arts, Section of Biological and Medical Sciences, and omitted from Scopus indexation and SCImago analysis in 2013. SCImago Journal Rank (SJR) for 2013 is available for Macedonian Journal of Chemistry and Chemical Engineering (SJR = 0.226), Macedonian Journal of Medical Sciences $(\mathrm{SJR}=0.213)$, Journal of Special Education and Rehabilitation (SJR =0.120), Bal- kan Journal of Medical Genetics $(\mathrm{SJR}=0.117)$, and BANTAO Journal (SJR = 0.102).

H5-index and h5-median for 2013 and 2012 were calculated for six scholarly biomedical journals from R. Macedonia and included in Google Scholar metrics (Table 5). At the top of the biomedical journals from R. Macedonia are Macedonian Journal of Chemistry and Chemical Engineering and Prilozi with an h5-index of 9 and h5-median of 21 and 13, respectively. The rest of the journals have smaller h5-indexes: Macedonian Journal of Medical Sciences: 7, Balkan Journal of Medical Genetics: 5, Journal of Special Education and Rehabilitation: 3, Macedonian Journal of Animal Science: 2. In comparison with 2012, all h5-indexes have increased except for Macedonian Journal of Animal Science. Similarly, all h5-mediana have increased in comparison with 2012 except for Prilozi. 
Table 5

Macedonian scholarly biomedical journals included in Google Scholar metrics (2013, 2012)

\begin{tabular}{|c|c|c|c|c|c|}
\hline \multirow{2}{*}{ Rank } & \multirow{2}{*}{ Journal } & \multicolumn{2}{|c|}{2013} & \multicolumn{2}{|c|}{2012} \\
\hline & & h5-index & h5-median & h5-index & h5-median \\
\hline 1. & $\begin{array}{l}\text { Macedonian Journal of Chemistry and } \\
\text { Chemical Engineering }\end{array}$ & $9 \uparrow$ & $21 \uparrow$ & 8 & 14 \\
\hline 2. & $\begin{array}{l}\text { Prilozi/Makedonska akademija na naukite i } \\
\text { umetnostite, Oddelenie za biološki i } \\
\text { medicinski nauki= Contributions/Macedonian } \\
\text { Academy of Sciences and Arts, Section of } \\
\text { Biological and Medical Sciences }\end{array}$ & $9 \uparrow$ & $13=$ & 8 & 13 \\
\hline 3. & Macedonian Journal of Medical Sciences & $7 \uparrow$ & $9 \uparrow$ & 6 & 8 \\
\hline 4. & Balkan Journal of Medical Genetics & $5 \uparrow$ & $8 \uparrow$ & 3 & 4 \\
\hline 5. & $\begin{array}{l}\text { Journal of Special Education and } \\
\text { Rehabilitation }\end{array}$ & $3 \uparrow$ & $4 \uparrow$ & 2 & 2 \\
\hline 6. & Macedonian Journal of Animal Science & $2=$ & $3 \uparrow$ & 2 & 2 \\
\hline
\end{tabular}

H5 - Index is the h-index for articles published in the last 5 complete years;

$\mathrm{h} 5$ - median for a publication is the median number of citations for the articles that make up its h5-index;

$\uparrow \downarrow$, increase or decrease in comparison with 2012 .

\section{Ranking researchers in the Republic} of Macedonia

The top twenty authors from the R. Macedonia according to abstracts indexed in PubMed semantically analysed with GoPubMed (1628 abstracts identified on November 02, 2014) and Google Scholar Hirsh-index (November 06, 2014) are shown in Table 6. The first place among the top 20 authors belongs to Polenakovic M (180 abstracts and Hirsh-index: 20), followed by Efremov G, Tasic V, Spasovski G, Gucev Z, Popov Z, Sikole A, Grcevska L, Petrusevska G, Stafilov T, Ivanovski N, Bosevski M, Spiroski M, Arsov T, Pop-Jordanova N, Cakalaroski K, Dzikova S, Kocarev L, Georgievska-Ismail L, and Stefova M. According the Hirsh-index, Efremov $\mathrm{G}$ is on the first place (Hirsh-index 31) followed by Kocarev L (Hirshindex $=30$, Stafilov T (Hirsh-index: 25), Spasovski $G$ (Hirsh-index: 22), and Polenakovic (Hirsh-index: 20). The rest of the researchers have a Hirsh-index lower than 20 (Table 6).

\section{Discussion}

In this paper the results of the current biomedical scientific impact (2013) of institutions, academic journals and researchers in $\mathrm{R}$. Macedonia are presented.
Country rank of subject area Medicine in the world for R. Macedonia for the period 1996-2013 ordered by Hirsh index (H-index) is the $110^{\text {th }}$ place with an $\mathrm{H}$ index of 45 . Bosnia and Herzegovina and Montenegro have a lower rank than R. Macedonia, but Slovenia, Croatia and Serbia have a higher rank in H-indexes. From 2009-12 only Ss Cyril and Methodius University, Skopje, (UC\&M) was included in the SCImago Institutions Rankings (SIR) with a world rank of 1726 to 1821 . It is very strange that of 20 accredited universities in R. Macedonia, only two published more than 100 papers per year. This means that the rest of the universities should stimulate authors and journals to publish more papers per year, preferably in journals included in the Scopus database, and it should be a tendency of each journal to reach such a level as a first step towards application for IF. A first analysis of biomedical institutions in R. Macedonia was published in 2009, when twelve Institutes at the Faculty of Medicine in Skopje, R. Macedonia, with 140 authors, were analysed with Harzing's Publish or Perish software [24] for their current scientific impact (August, 2009) [25]. The paper was treated by some researchers as an individual attack on their integrity with an avalanche of reactions, 
including the Ethics Committee of the Faculty of Medicine, instead of a positive approach to scientific measurement with motivation and support for improving scientific publication of researchers from the Institutes at the Faculty of Medicine in Skopje.

Table 6

Top twenty authors from the Republic of Macedonia according to abstracts indexed in PubMed semantically analysed with GoPubMed (1628 abstracts identified on November 02, 2014) and Google Scholar Hirsh-index (November 06, 2014)

\begin{tabular}{|c|c|c|c|c|}
\hline \multirow[b]{2}{*}{ Author } & \multicolumn{2}{|c|}{ PubMed } & \multicolumn{2}{|c|}{ Google Scholar } \\
\hline & $\begin{array}{c}\text { Number } \\
\text { of Abstracts }\end{array}$ & $\begin{array}{c}\text { Rank } \\
\text { of Abstracts }\end{array}$ & Hirsh index & $\begin{array}{l}\text { Rank of Hirsh } \\
\text { index }\end{array}$ \\
\hline "Polenakovic M" OR "Polenankovik M" & 180 & 1 & 20 & 5 \\
\hline "Efremov G" & 154 & 2 & 31 & 1 \\
\hline "Tasic V" & 111 & 3 & 17 & 7 \\
\hline "Spasovski G" & 105 & 4 & 22 & 4 \\
\hline "Gucev Z" OR "Guchev Z" & 76 & 5 & 14 & $11-12$ \\
\hline "Popov Z" & 61 & $6-7$ & 15 & $8-10$ \\
\hline "Sikole A" & 61 & $6-7$ & 15 & $8-10$ \\
\hline "Grcevska L" OR "Grchevska L" & 60 & 8 & 9 & $15-17$ \\
\hline "Petrusevska G" OR "Petrushevska G" & 59 & 9 & 10 & $13-14$ \\
\hline "Stafilov T" & 56 & 10 & 25 & 3 \\
\hline "Ivanovski N" & 55 & $11-12$ & 9 & $15-17$ \\
\hline "Bosevski M" & 55 & $11-12$ & 8 & 18 \\
\hline "Spiroski M" OR "Spirovski M" & 54 & 13 & 14 & $11-12$ \\
\hline "Arsov T" NOT "Bulgaria" & 46 & 14 & 19 & 6 \\
\hline "Pop-Jordanova N" & 43 & 15 & 10 & $13-14$ \\
\hline "Cakalaroski K" OR "Chakalaroski K" & 37 & 16 & 7 & 19 \\
\hline "Dzikova S" & 32 & 17 & 9 & $15-17$ \\
\hline "Kocarev L" & 29 & 18 & 30 & 2 \\
\hline "Georgievska-Ismail L" & 27 & $19-20$ & 5 & 20 \\
\hline "Stefova M" & 27 & $19-20$ & 15 & $8-10$ \\
\hline
\end{tabular}

A search of the Scopus database was performed on February 23, 2013 in order to identify published papers from the field of medical sciences affiliated to the country Macedonia. A total number of 967 articles were selected for analysis and the h-index was calculated from these documents. The papers were published in a total of 160 journals. The largest number of papers was published in domestic journals. Two scientists are the top two, with 59-65 published papers, the next group of eight scientists had published 25-44 papers, and the remaining authors had published fewer than 25 papers each. The published papers had been cited 4380 times (mean citation of 4.5 per paper) with the Hirsh index (H-index) of 27 [26].

Six medical journals from R. Macedonia are included in the Scopus database (Macedonian Journal of Chemistry and Chemical Engineering, Macedonian Journal of Medical Sci- ences, Balkan Journal of Medical Genetics, Prilozi, Journal of Special Education and Rehabilitation and BANTAO Journal). Source Normalized Impact per Paper (SNIP) and Impact per Publication (IPP) were calculated for only three journals (Macedonian Journal of Chemistry and Chemical Engineering, Macedonian Journal of Medical Sciences and Balkan Journal of Medical Genetics). SCImago Journal Rank (SJR) was calculated for four journals (Macedonian Journal of Chemistry and Chemical Engineering, Macedonian Journal of Medical Sciences, Balkan Journal of Medical Genetics, and Prilozi). H5-index and h5-median for 2013 and 2012, included in Google Scholar metrics, show that at the top of the biomedical journals from R. Macedonia are Macedonian Journal of Chemistry and Chemical Engineering and Prilozi, followed by Macedonian Journal of Medical Sciences, Balkan Journal of Medical Genetics, 
Journal of Special Education and Rehabilitation, and Macedonian Journal of Animal Science.

The Scopus Journal Analyzer provides a measure of journal performance back to 1996 . The Scopus Journal Analyzer includes 3 journal metrics: SNIP (Source Normalized Impact per Paper), measures citation impact by weighting citations based on the total number of citations in a specific subject field [20]; IPP (Impact per Publication) measures the ratio of citations in a year of scholarly papers published in the three previous years divided by the number of scholarly papers published in those same years [21]; and SJR (SCImago Journal Rank) is a prestige measure based on the idea that all citations are not created equal [18]. With SJR, the subject field, the quality and reputation of the journal have a direct effect on the value of a citation [17]. The impact of a single citation is given a higher value in subject areas where citations are less likely, and vice versa [21, 27]. The SJR and SNIP of Macedonian biomedical journals are indicators of the quality of these journals.

A total of 37 medical journals have been published in R. Macedonia since the Second World War, either in printed or electronic version [28]. Data referring to 14 titles of journals were obtained from COBIB.MK, but unfortunately only six of them are indexed in the Scopus database, which is an unacceptably low inclusion. It was concluded that our medical journals should become a school on how medical problems are treated and how to prepare a paper for medical journals. However, the authors concluded that it is necessary to reach the European level of basic and clinical research in medical science in R. Macedonia [28].

The first place of the top 20 authors from R. Macedonia according to the number of abstracts indexed in PubMed semantically analyzed with GoPubMed belongs to M Polenakovic (180 abstracts and Hirsh-index 20), but according the Hirsh-index G Efremov is in the first place with a Hirsh-index of 31. The rank of Hirsh index (h-index) was different from the rank of number of abstracts indexed in PubMed for the top 20 authors from R. Macedonia.

Researcher's impact was analyzed with $\mathrm{H}$-index for the employees of the Institutes at the Faculty of Medicine in Skopje using the
Scopus database [29], as also for biomedical researchers included and indexed in PubMed [23]. The results show that a very small number of biomedical researchers are among the top 10 or top 20 authors. Ss Cyril and Methodius University, Skopje, started stimulation of researchers, introducing Top 10 Authors for the previous year. Unfortunately, the cumulative number of published papers is used as a ranking criterion instead of $\mathrm{H}$-index or other verified indexes for the quality of scientific impact. It would be more effective and objective to use verified scientific indexes for stimulation of researchers in all universities in R. Macedonia.

Several problems arise when author impact analysis search is used: i) some authors have used different names in different periods of time; ii) some authors transliterate their names in several different ways; iii) some authors add or do not add "v"; iv) some authors use only one of their two surnames; v) there are some identical names and surnames for different researchers in the world [29]. All of these variables are recognized as author ambiguity. There are several ambiguous researchers in the top 20 authors from R. Macedonia, but unfortunately PubMed do not have a tool for ambiguity resolution and because of this the precise results of the top 20 authors should be treated very carefully. One of the effective solutions for ambiguity resolution is registration of researchers in the ResearchersID (http://www.researcherid.com/) [30] and in the ORCID (http://orcid.org/) [31].

Publication ethics established by the Editorial Boards of Macedonian medical journals are in the very early stage, with very rare use of tools for checking similarities between submitted manuscripts and published papers. There are ten papers with very great similarities deposited in Deja vu database from the medical scientists of R. Macedonia [32]. Only two retractions have been recorded in the Scopus database from R. Macedonia: one was a Master of Science thesis from a Macedonian author [33] and another on clinical science from a Serbian author [34]. At the moment only two Macedonian biomedical journals are members of the Committee on Publication Ethics (COPE) (Macedonian Journal of Medical Sciences and Macedonian Veterinary Review). Obviously, more efforts are needed from the Editors-in-Chief of 
Macedonian biomedical journals to implement international ethical standards in the publication process [35].

In conclusion, the rank of subject area Medicine for R. Macedonia according the SCImago Journal \& Country Rank (SJR) is 110th in the world and 17th in Eastern Europe. Of 20 universities in R. Macedonia, only Ss Cyril and Methodius University, Skopje, and St Clement of Ohrid University, Bitola, are listed in SCImago Institutions Rankings (SIR) for 2013. A very small number of Macedonian scholarly journals is included in Web of Science (2), PubMed (1), PubMed Central (1), SCOPUS (6), SCImago (6), and Google Scholar metrics (6). The rank of Hirsh index (h-index) was different from the rank of number of abstracts indexed in PubMed for the top 20 authors from R. Macedonia. The current biomedical scientific impact (2013) of institutions, academic journals and researchers in R. Macedonia is very low. There is an urgent need to organize measures to improve the quality and output of institutions, scholarly journals, and researchers in Macedonia in order to achieve higher international standards.

\section{Acknowledgements}

I would like to thank the present members of the Editorial Board of Mac J Med Sci (2013-) (Doncho Donev, Elizabeta MukaetovaLadinska, Marko Spasov, Sasho Stoleski, Ivo Spiroski, and Katarina Stavric), as well past members of the Editorial Board of Mac J Med Sci (2008-2012) (Jean Gogusev, Stojmir Petrov, Dejan Trajkov, Aleksandar Petlichkovski, Slavica Hristomanova, Meri Kirijas, Aleksandar Senev, and Natasha Arsova) for their close cooperation and the continuous increase in the quality of the Macedonian Journal of Medical Sciences.

\section{REFERENCES}

1. Bornmann L, de Moya-Anegón F, Leydesdorff L. The new excellence indicator in the World Report of the SCImago Institutions Rankings 2011. arXiv preprint arXiv. 2011; 1110.2305.

2. Kianifar H, Sadeghi R, Zarifmahmoudi L. Comparison Between Impact Factor, Eigenfactor Metrics, and SCimago Journal Rank Indicator of Pediatric Neurology Journals. Acta Inform Med. 2014; 22(2): 103-6.
3. Garfield E. Which medical journals have the greatest impact? Ann Intern Med. 1986; 105(2): 313-20.

4. European Association of Science Editors (EASE) Statement on Inappropriate Use of Impact Factors. Available at:

http://www.ease.org.uk/sites/default/files/ease_statem ent_ifs_final.pdf. Accessed: Oct. 8, 2014.

5. International Council for Science statement. Icsu.org. Available at:

http://www.icsu.org/publications/cfrs-statements/pub lication-practices-peer-review/statement-publicationpractices-and-indices-and-the-role-of-peer-review-inresearch-assessment-july-2008. 2014-05-02.

Accessed: May 18, 2014

6. DFG press release. Available at: http://www.dfg.de/en/service/press/press_releases/20 10/pressemitteilung_nr_07/index.html Accessed: Oct. 8, 2014

7. Berkeley Research. Addressing Broader Impacts. Available at:

http://vcresearch.berkeley.edu/brdo/addressing-broader-impacts. Accessed: Oct. 10, 2014

8. Eyre-Walker A, Stoletzki N. The assessment of science: the relative merits of post-publication review, the impact factor, and the number of citations. PLoS Biol. 2013; 11(10): e1001675.

9. Bladek M. DORA: San Francisco Declaration on Research Assessment (May 2013). Coll Res Libr News. 2014; 75: 191-196.

10. Radicchi F, Fortunato S, Markines B. Vespignani A. Diffusion of scientific credits and the ranking of scientists. Phys Rev. 2009; E 80.

11. Hirsch JE. Does the H index have predictive power? Proc Natl Acad Sci U S A. 2007; 104(49): 19193-8.

12. Pan RK, Fortunato S. Author Impact Factor: tracking the dynamics of individual scientific impact. Sci Rep. 2014; 4: 4880.

13. Spiroski M. Macedonian biomedical scientists are not adequately represented in BiomedExperts database. Maced J Med Sci. 2008; 1(1): 13-17.

14. Spiroski M, Gogusev J. Macedonian Medical Journals Have Very Limited Scientific Influence. Maced J Med Sci. 2008; 1(2): 10-16.

15. Spiroski M. Country Rank, Journal Rank and HIndex in the Field of Medicine in the Republic of Macedonia (1996-2008) Using Data from SCImago. Maced J Med Sci. 2010; 3(2): 99-108.

16. Mukaetova-Ladinska EB, Korneti-Pekevska K. A Macedonian Biomedical Science: Current Standing and Suggestions for Improvement. Maced J Med Sci. 2010; 3(1): 5-8.

17. González-Pereira B, Guerrero-Bote V, Moya-Anegon F. The SJR indicator: A new indicator of journals' scientific prestige. arXiv preprint arXiv. 2009; 0912.4141 .

18. SCImago. SJR - SCImago Journal \& Country Rank. 2007

Retrieved October 04, 2014, from http://www.scimagojr.com

19. Journal Metrics. http://www.journalmetrics.com/ Accessed October 10, 2014 
20. Waltman L, van Eck NJ, van Leeuwen TN, Visser MS. Some modifications to the SNIP journal impact indicator. Journal of Informetrics. 2013; 7(2): 272-285.

21. Moed HF. Measuring contextual citation impact of scientific journals. Journal of Informetrics. 2010; 4(3): 265-277.

22. Cabezas-Clavijo A, Delgado-López-Cózar E. [Google Scholar and the h-index in biomedicine: the popularization of bibliometric assessment]. Med Intensiva. 2013; 37(5): 343-54.

23. Spiroski M. Semantic Analysis of Macedonian Medical Abstracts Indexed in the PubMed Database using GoPubMed. Maced J Med Sci. 2013; 6(2): $135-140$

24. Harzing AW. Publish or Perish, 2007. Available at: http://www.harzing.com/pop.htm Accessed: Oct. 8, 2014.

25. Spiroski M. Current Scientific Impact of the Institutes, Faculty of Medicine, Ss Cyril and Methodius University, Skopje, Republic of Macedonia. Maced J Med Sci. 2009; 2(3): 187-195.

26. Spiroski M. Analysis of Macedonian Medical Scientific Papers in the Scopus Database. Maced J Med Sci. 2013; 6(1): 5-10.

27. Moed HF, Colledge L, Reedijk J, Moya-Anegon F, Guerrero-Bote V, Plume A, Amin M. Citation-based metrics are appropriate tools in journal assessment provided that they are accurate and used in an informed way. Scientometrics. 2012; 92(2): 367-376.

28. Polenakovic M, Danevska L. Medical journals in the Republic of Macedonia after the Second World War. Prilozi. 2011; 32(2): 11-31.

29. Spiroski M. Who is Who-Current Scientific Impact of the Medical Staff Affiliated at the Institutes, Faculty of Medicine, Ss Cyril and Methodius University, Skopje, Republic of Macedonia. Maced J Med Sci. 2009; 2(4): 285-293.

30. Zhaohui LHC. Building a New Institutional Repository Based on the Knowledge Network of Researchers: A case of Researcher ID [J]. Researches in Library Science, 2010; 6: 006.

31. Anstey A. How can we be certain who authors really are? Why ORCID is important to the British Journal of Dermatology. Br J Dermatol. 2014; 171(4): 679-80.

32. Spiroski M. Déjà vu: A report of highly similar citations in the Biomedical scientific literature from the Republic of Macedonia. Maced J Med Sci. 2009; 2: 107-114.

33. Spiroski M. Retraction: Ana Strezova. Genotyping of HLA-A, HLA-C and HLA-B Loci with Reverse Line Strip Hybridization in Macedonian Population and Association of HLA Class I Alleles with Spondilitis [MSc thesis]. Maced J Med Sci. 2010; 3(2): 188-191.

34. Spiroski M. Retraction: Sleep Organisation in Depression and Schizophrenia: Index of Endogenous Periodicity of Sleep as a State Marker. Maced J Med Sci. 2014 Jun 15; 7(2): 319.

35. Graf C, Wager E, Bowman A, Fiack S, Scott-Lichter D, Robinson A. Best practice guidelines on publication ethics: a publisher's perspective. International Journal of Clinical Practice. 2007; 61(s152): 1-26.
Р е $з$ и ме

\section{СЕГАШНО БИОМЕДИЦИНСКО \\ НАУЧНО ВЛИЈАНИЕ (2013) \\ НА ИНСТИТУЦИИТЕ, АКАДЕМСКИТЕ \\ СПИСАНИЈА И ИСТРАЖУВАЧИТЕ ОД РЕПУБЛИКА МАКЕДОНИЈА}

ирко пироски

Медицински факултет, Универзитет „Св. Кирил и Методиј“, Скопје, Република Македонија; основач и главен и одговорен уредник на "Macedonian Journal of Medical Sciences"

ел: Анализа на сегашното рангирање (2013) на институциите, списанијата и истражувачите од Република Македонија.

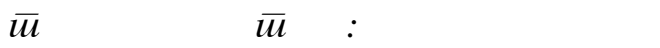
Република Македонија беше анализирано со SCImago Country \& Journal Rank (SJR) за подрачјето медицина во годините 1996-2013 и рангирано според Хиршовиот индекс. SCImago Institutions Rankings за 2013 година беше користен за испитување на научното влијание на биомедицинските институции од Република Македонија. Метриската анализа од Елсевиер беше употребена за анализа на македонските академски списанија за периодот 2009-2013 година. Беа анализирани Source Normalized Impact per Paper (SNIP), Impact per Publication (IPP) и SCImago Journal Rank (SJR). Македонските биомедицински списанија вклучени во Google Scholar metrics (2013, 2012 ) беа анализирани со $\mathrm{x} 5$-индекс и $\mathrm{x} 5$-медијана (2014). Семантичка анализа на базата на податоци PubMed беше направена со GoPubMed на 2 ноември 2014 година за да се идентифицираат објавените трудови од биомедицинските научни работници во Република Македонија. Софтверот Harzing's Publish or Perish беше употребен за анализа на влијанието на авторите и пресметување на Хиршовиот индекс врз основа на пребарувањето во Google Scholar.

езулй $\bar{u} u:$ Рангот на подрачјето медицина во Република Македонија според SCImago Journal \& Country Rank (SJR) и според Хиршовиот индекс е 110 . место во светот и 17. место во Источна Европа. Од 20 универзитети во Република Македонија, само Универзитетот „Св. Кирил и Методиј“ од Скопје и Универзитетот „Св. Климент Охридски“ од Битола се внесени во SCImago Institutions Rankings (SIR) за 2013 година. Многу мал дел од македонските академски списанија се вклучени во Web of Sciences (2), PubMed (1), PubMed Central (1), SCOPUS (6), 
SCImago (6), и Google Scholar metrics (6). Рангот според Хиршовиот индекс (h-index) е различен од рангот според бројот на извадоци индексирани во PubMed за врвните 20 автори од Република Македонија.

клучок: Сегашното биомедицинско влијание (2013) на институциите, академските списанија и истражувачите е многу мало. Потребно е итно и организирано подобрување на квалитетот на институциите, академските списанија и истражувачите за да се достигнат повисоки меѓународни стандарди.

лучни зборови: медицинска наука, Scopus база на податоци, мерење цитираност, Хиршов индекс, Република Македонија. 